\title{
The Volatility of Export Amount \& the Number of Exports of Korea's Major Exporting Countries
}

\author{
Soo-Ho Choi, Jeong-Il Choi
}

\begin{abstract}
The purpose of this study is to predict future directions and trends in the number of exports, export amount, the number of imports and import amount of major exporting countries in Korea. Major exporting countries selected China, the United States, Vietnam, Hong Kong, Japan and Taiwan as export orders. The data required for this study was collected from the trade statistics of the Korea Customs Service. The analysis period for major exporting countries is 225 months from January 2000 to September 2018, using monthly and annual data. Monthly data were model, index and numerical analysis using Excel, e-views and SPSS. In the growth rate analysis, Vietnam showed $780 \%$ the number of exports, 3,000\% exports amount, 2,400\% the number of imports and 6,200\% imports amount. For the past 19 years, Vietnam has shown the highest growth rate compared to other countries. The correlation between the number of exports, export amount, the number of imports and import amount showed that the value of export amount and import amount was as high as 0.960. In the monthly regression analysis of exports, China, USA, Hong Kong, Japan and Taiwan were statistically significant at $t$-statistic and p-value $(\leq 0.01)$ except for Vietnam. Analysis results, this study shows that Vietnam, Hong Kong and Taiwan have relatively higher growth and volatility than the US and Japan in the past export market. Southeast Asian markets including Vietnam, Hong Kong and Taiwan are emerging as new export markets. In addition, Korea needs more attention to Asian markets including India, Singapore, Thailand, Malaysia and Philippines. It is necessary to diversify the export market and the import market because the export amount and the import amount are increasing in proportion to each other. This paper will help diversify Korea's major exporting and importing countries in the future.
\end{abstract}

Keywords : the number of Exports, Export Amount, the number of Imports, Import Amount, Volatility

\section{INTRODUCTION}

Korea achieved per capita income of US \$30,000 and exported US $\$ 600$ billion (seventh) in 2018. To achieve $\$ 700$ billion in exports, we need to diversify our export structure, which is focused on some items. In addition, export dependency should be improved by improving reliance on foreign countries. The purpose of this study is to predict future directions and trends in the number of exports, export amount, the number of imports and import amount of major exporting countries in Korea. Major exporting countries selected China, the United States, Vietnam, Hong Kong, Japan and Taiwan as export orders.

The data required for this study was collected from the

Revised Manuscript Received on July 22, 2019

Soo Ho, Choi, Division of Business, Sogang University, Mapo-gu, Seoul, Korea, Email: shchoi88@ sogang.ac.kr

Jeong Il, Choi*, Division of Business, Sungkyul University, Anyang, Gyeonggi-do, Korea, Email: cji3600@hanmail.net trade statistics of the Korea Customs Service. The analysis period for major exporting countries is 225 months from January 2000 to September 2018, using monthly and annual data. The major countries are represented as Korea, China, USA, Vietnam, HK, Japan, and Taiwan for convenience. Monthly data used in this study were model, index and numerical analysis using Excel, e-views and SPSS. Using this data, this study examines the number of exports, exports, the number of imports and imports in each country and examines the effect on total exports of Korea. In addition, this study examines which countries will increase exports in the future, and compares the rate of increase and the rate of change in exports by each country.

\section{PRECEDENT RESEARCH}

\section{A. China}

Choi, M. S.(2017) analyzed that there is a strong link between China's global exports and Korea's exports to China. If trade friction intensifies between the US and China, Korea's exports to China will have a negative(-) impact. Choi, E. H. (2017) suggested that China's electronics industry investment will increase exports to related industries such as chemical, machinery and precision machinery. Investments in capital goods and intermediate goods have increased the export of capital goods. Yoo, G. H. (2017) suggested that logistics should be used efficiently for effective export strategy. And this paper proposed a strategy for developing CBT(cross border trade) exports to China. Kang, S. G. (2016) analyzed the export competitiveness of Korean agriculture products as follows. First, export expansion through e-commerce Second, targeting consumers through target setting Third, cost reduction through improvement of distribution logistics system Fourth, expanding market share through utilization of Korea-China FTA.

\section{B. USA}

Kim, W. J. (2017) analyzed that direct investment in China is a substitute for Korea's exports to the United States. In particular, the study suggests that substitution effects in consumer goods exports were significant. Kim, J. Y. (2017) has identified the reasons for the decline in US market competitiveness after the Korea-US FTA. And he argued that policy support was needed. Cha \& Kim (2016) analyzed that the impact of US interest rate hike shocks differed by industry. And it is estimated that the effect on total domestic exports will not be significant. Shim, J. H. (2017) argues that, while enhancing the competitiveness of service trade, 
it should pursue a balance of benefits in services and products in FTA negotiations with the US.

\section{Vietnam}

Kim, C. B. et al. (2017) analyzed the effect of Vietnam's direct investment on exports as follows: First, the amount of direct investment in Vietnam had a positive $(+)$ effect on exports. Second, the number of direct investments in Vietnam had a positive (+) effect on exports and exports portion. Choi, D. O. et al. (2015) analyzed that Korean exports to Vietnam are centered on air rather than on the sea. Exports of semiconductors through aviation have been increasing even as exchange rates have fallen. In order to increase exports to Vietnam, Lee, J. H. (2012) investigated that manager's international experience has a positive $(+)$ effect on exports. In addition, the quality differentiation of products exported to Vietnam has a significant influence on exports. Lee \& Lee (2015) analyzed that a high level sustainable supply chain is being implemented in Southeast Asia. It has a positive effect on the improvement of performance in terms of society, environment and production operation of suppliers.

\section{Hong Kong}

Lee, Y. H. (2018) reported that Korean pork was positively evaluated by Hong Kong consumers. Korean pork has an excellent taste and flavor, and $70 \%$ of Hong Kong consumers are willing to purchase it, which is likely to increase its market share. Jung, B. N. (2017) announced that the NACF will export Jeju black pork through an agreement with Hong Kong, and plans to further expand its export market in the future. The NACF will aggressively pioneer the Hong Kong market and plan to achieve export sales of more than \$21 million by 2020. Ministry of Agriculture, Food \& Rural Affairs (2018) said that Korean chicken, duck and eggs could be exported to Hong Kong from July 27, 2018. Exports are expected to increase further in the future. In order to expand Hong Kong exports in the future, it announced that it will do its best for on-site quarantine and support. MAFRA also plans to show interest in quarantine and hygiene management so that safe and superior products can be exported.

\section{E. Japan}

Oh, T. H. (2017) draws implications for Korea's export expansion to Japan as follow: First, Japan has been steadily increasing its imports from Asia in recent years. Second, Korea's export to Japan should be concerned with clothing, semiconductors, telecommunication equipment, pharmaceuticals, and automobile parts. Second, Korea's export to Japan should be concerned with clothing, semiconductors, telecommunication equipment, pharmaceuticals and automobile parts. Kwon \& Nam (2013) said that there is a market dominant company in the electric power market in Japan and can understand the change. Therefore, Korean companies have proposed a strategy of export business linkage in Japan to cope with market changes. Kwon \& Nam (2013) investigated that Korean automobile and electronic products are sluggish in the Japanese market. This paper suggests that Korean firms respond to the 'Product differentiation of Japanese companies' by cost advantage strategy and differentiation strategy. Jung \& Im (2018) analyzed that ICT industry exports are at risk due to the high manufacturing cost of Japan and the pursuit of the latter countries. Therefore, ICT in Japan is in decline due to delayed development of new growth engine.

\section{F. Taiwan}

Lim, C. R. et al. (2011) examined the effect of Taiwanese consumers on GAP (Good Agricultural Practice) certification. This paper suggested that GAP certification should be strengthened by the government in order to facilitate the export of apples to Taiwan. Choi, S. I. (2017) said that CEO Lee has been exporting pears to Taiwan since 1998. CEO Lee has exported 1000-1500 boxes of $5 \mathrm{~kg}$ boxes per year to Taiwan with the best pear. And he is producing delicious pear in keeping with Taiwan's accepted crop protection regulations. Korea's exports of kimchi to the United States and Taiwan are steadily increasing. The Korean machine tool manufactures is experiencing a decline in exports to Japan and the United States, but exports are increasing in Taiwan. The Korea International Trade Association (2016) reported that in Taiwan, the demand for optical instruments, laser devices and fans is increasing and that Korea's exports will increase due to the elimination of tariffs. In addition, Taiwan is expected to benefit from ITA II (Information Technology Agreement) as a non-FTA partner.

\section{DATA COLLECTION \& MAJOR EXPORTING COUNTRIES}

\section{A. Data Collection}

The purpose of this study is to predict future directions and trends in the number of exports, exports, the number of imports and imports of major exporting countries in Korea. Major exporting countries selected China, USA, Vietnam, Hong Kong, Japan and Taiwan as export orders. The data required for this study was collected from the trade statistics of the Korea Customs Service. The analysis period for major exporting countries is 225 months from January 2000 to September 2018, using monthly and annual data.

The major countries are represented as Korea, China, USA, Vietnam, HK, Japan, and Taiwan for convenience. Monthly data used in this study were model, index and numerical analysis using Excel, e-views and SPSS. Using this data, this study examines the number of exports, exports, the number of imports and imports in each country and examines the effect on total exports of Korea. In addition, this study examines which countries will increase exports in the future, and compares the rate of increase and the rate of change in exports by each country.

\section{B. Major Exporting Countries}

For the 21 months from January 2017 to September 2018, Korea's total exports amounted to $\$ 1,024,005$ million, with the top 6 countries accounting for $60.8 \%$ of $\$ 622,756$ million in the Table- I. The analysis period in the following figure is the monthly data of 2000-2018. 
Table- I: Korea's Major Export Country (period: 2017.01-2018.09, unit: 1 million\$)

\begin{tabular}{c||ccccc}
\hline & $\begin{array}{c}\text { Number of } \\
\text { Exports }\end{array}$ & $\begin{array}{c}\text { Export } \\
\text { Amount }\end{array}$ & $\begin{array}{c}\text { Number of } \\
\text { Imports }\end{array}$ & $\begin{array}{c}\text { Import } \\
\text { Amount }\end{array}$ & $\begin{array}{c}\text { Trade } \\
\text { Balance }\end{array}$ \\
\hline \hline China & 4,095 & 264,016 & 5,748 & 175,006 & $\mathbf{8 9 , 0 0 9}$ \\
USA & 1,637 & 121,087 & 15,101 & $\mathbf{9 3 , 7 9 9}$ & $\mathbf{2 7 , 2 8 8}$ \\
Vietnam & 1,084 & $\mathbf{8 3 , 5 1 4}$ & $\mathbf{5 7 6}$ & $\mathbf{3 0 , 5 6 4}$ & $\mathbf{5 2 , 9 5 0}$ \\
HK & $\mathbf{5 7 4}$ & $\mathbf{7 5 , 2 6 9}$ & $\mathbf{3 4 6}$ & $\mathbf{3 , 4 2 7}$ & $\mathbf{7 1 , 8 4 2}$ \\
Japan & 1,430 & 49,446 & $\mathbf{3 , 0 6 1}$ & $\mathbf{9 6 , 1 5 5}$ & $\mathbf{- 4 6 , 7 0}$ \\
Taiwan & 430 & 29,421 & $\mathbf{5 1 9}$ & $\mathbf{3 0 , 7 5 7}$ & $\mathbf{- 1 , 3 3 5}$ \\
Australia & 200 & 27,229 & 576 & $\mathbf{3 4 , 2 3 4}$ & $\mathbf{- 7 , 0 0 5}$ \\
India & 379 & $\mathbf{2 6 , 8 2 0}$ & 172 & $\mathbf{9 , 1 4 7}$ & $\mathbf{1 7 , 6 7 2}$ \\
Singapore & 379 & $\mathbf{1 9 , 9 3 3}$ & $\mathbf{2 7 3}$ & $\mathbf{1 4 , 8 6 3}$ & $\mathbf{5 , 0 6 9}$ \\
Mexico & 237 & 19,499 & 137 & $\mathbf{8 , 3 0 5}$ & $\mathbf{1 1 , 1 9 3}$ \\
\hline
\end{tabular}

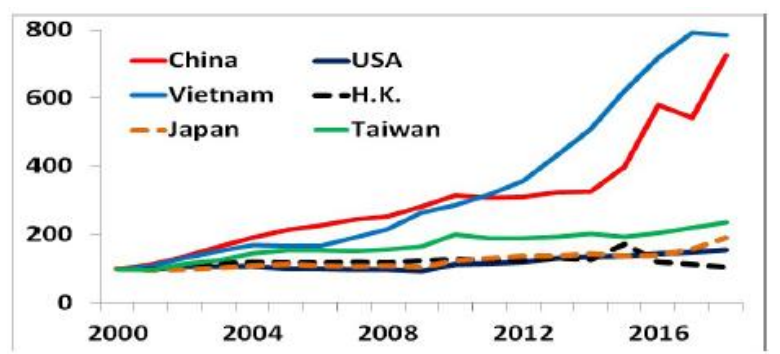

Fig. 1.the number of Export

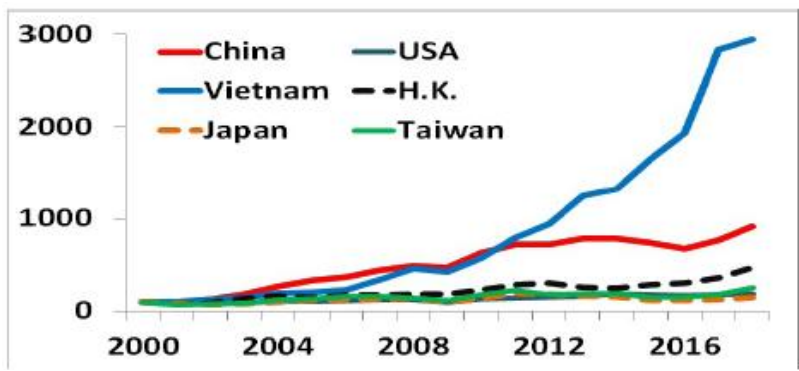

Fig. 2. Export Amount

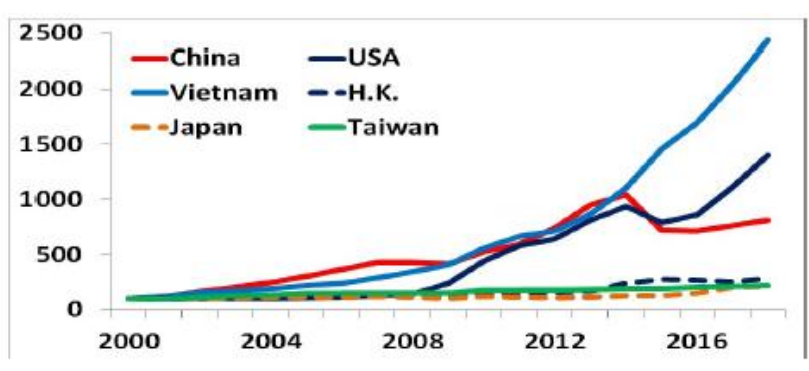

Fig. 3. the number of Import

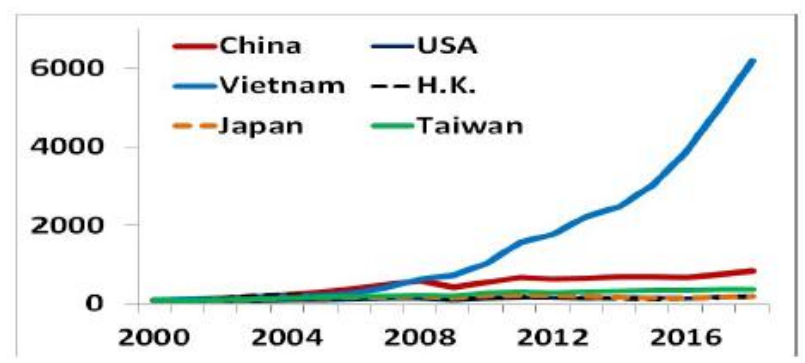

Fig. 4. Import Amount

This study examines the growth rate for 19 years up to 2018 based on $2000(=100)$. As a result, the number of exports rose by more than $700 \%$ in Vietnam and China in Figure 1. In Figure 2, exports amounts show 3,000\% in Vietnam and $1,000 \%$ in China. In Figure 3, the number of imports rose to $2,500 \%$ in Vietnam, $1,500 \%$ in the US and $1,000 \%$ in China. In Figure 4, imports amounts show 6,000\% in Vietnam and below $1,000 \%$ in other countries. Over the past 19 years, Vietnam's growth has been most visible.

Table- I: Annual Correlation Analysis

\begin{tabular}{ccccc}
\hline & $\begin{array}{c}\text { The Number } \\
\text { of Exports }\end{array}$ & $\begin{array}{c}\text { Export } \\
\text { Amount }\end{array}$ & $\begin{array}{c}\text { the Number of } \\
\text { Import }\end{array}$ & $\begin{array}{c}\text { Import } \\
\text { Amount }\end{array}$ \\
\hline $\begin{array}{c}\text { the Number of } \\
\text { Exports }\end{array}$ & 1 & & & \\
$\begin{array}{c}\text { Export Amount } \\
\text { the Number of } \\
\text { Import }\end{array}$ & 0.321 & 1 & & \\
$\begin{array}{c}\text { Import Amount } \\
\text { Improt }\end{array}$ & 0.251 & 0.960 & 0.442 & 1 \\
\hline
\end{tabular}

In yearly correlation analysis, export amount and import amount are very high at 0.960 in Table- I. Korea has a high proportion of the improvement trade, so that export amount and import amount increase in proportion to each other.

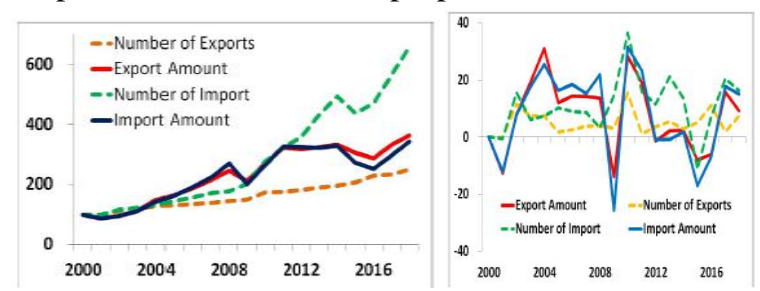

Fig. 5. the number of Import Fig. 6. Import Amount

The analysis period in the above figure is the monthly data of 2000-2018. The annual growth rate is higher in the order of the number of imports, export amount, import amount and the number exports in Figure 5. Import amount and export amount express relatively high compared to the number of exports and the number of imports in Figure 6.

\section{EMPIRICAL ANALYSIS}

\section{A. Numerical Analysis}

The correlation of exports of major exporting countries is shown in Table-III Over the past 19 years, Korea's exports have been highly correlated in order of US, China, Japan, Vietnam, Taiwan and Hong Kong. In the future, Korea's exports will be diverted from Vietnam and Hong Kong to Taiwan out of the past US and Japan.

Table-IV shows the exports descriptive statistics of major exporting countries. The average was higher in the order of Vietnam (2.94\%), China (1.47\%), Hong Kong (1.46\%) and Taiwan (1.21\%). Standard deviations were higher in the order of Vietnam (16.8), Hong Kong (11.5), the USA (11.4) and Taiwan (11.2). Vietnam, Hong Kong and Taiwan are emerging as new markets with high growth in export amount. 
Table-IV: the Descriptive Statistics: Export Amount

\begin{tabular}{cccccccc}
\hline & Korea & China & USA & Vietn. & HK & JAP & Taiwn \\
\hline Mean & 0.952 & 1.471 & 0.97 & 2.939 & 1.460 & 0.630 & 1.210 \\
Med. & 0.522 & 1.205 & -0.20 & 1.516 & 0.675 & 0.357 & 0.874 \\
Max. & 24.918 & 35.12 & 36.27 & 64.32 & 40.59 & 36.36 & 39.51 \\
Min. & -22.28 & -29.07 & -28.3 & -38.82 & -30.0 & -26.55 & -30.27 \\
S. D. & 8.016 & 8.707 & 11.35 & 16.810 & 11.54 & 9.257 & 11.239 \\
Skew & 0.139 & 0.450 & 0.535 & 0.579 & 0.530 & 0.151 & 0.342 \\
Kurt & 3.276 & 4.734 & 3.529 & 3.843 & 3.862 & 3.631 & 3.406 \\
J-Bar & 1.443 & 35.82 & 13.37 & 19.24 & 17.50 & 4.601 & 5.952 \\
a & 0.485 & 0.000 & 0.001 & 0.000 & 0.000 & 0.100 & 0.050 \\
Prob. & 225 & 225 & 225 & 225 & 225 & 225 & 225 \\
N & & & & & & & \\
\hline
\end{tabular}

Table- V: Regression Analysis : Export Amount

\begin{tabular}{ccccc}
\hline Variables & Coeffi. & Sd. Errr & t-Stati. & Prob \\
\hline C & -0.076 & 0.256 & -0.296 & 0.766 \\
China & 0.204 & 0.046 & 4.365 & 0.000 \\
USA & 0.242 & 0.032 & 7.425 & 0.000 \\
Vietnam & 0.035 & 0.020 & 1.783 & 0.075 \\
HK & 0.109 & 0.026 & 4.138 & 0.000 \\
Japan & 0.171 & 0.035 & 4.773 & 0.000 \\
Taiwan & 0.096 & 0.029 & 3.272 & 0.001 \\
R-squared & 0.784 & Mean dependent var & 0.952 \\
Adjusted R-squared & 0.778 & S.D. dependent var & $\mathbf{8 . 0 1 6}$ \\
S.E. of regression & 3.770 & Akaike info criterion & 5.522 \\
Sum squard R & 3099.4 & Schwarz criterion & 5.629 \\
Log likelihood & -614.3 & Hannan-Quinn criter. & 5.565 \\
F-statistic & 132.40 & Durbin-Watson stat & 2.954 \\
Prob(F-stat.) & 0.000 & & & \\
\hline & & &
\end{tabular}

Estimation Equation : Korea $=\mathrm{C} 1+\mathrm{C} 2 \cdot \mathrm{China}+\mathrm{C} 3 \cdot \mathrm{USA}$ + C4·Vietnam + C5·HK + C6·Japan + C7·Taiwan

Substituted Coefficients : Korea $=-0.076+0.204 \cdot$ China $+0.242 \cdot$ USA $+0.035 \cdot$ Vietnam $+0.109 \cdot \mathrm{HK}+0.171 \cdot \mathrm{Japan}+$ 0.096.Taiwan

Table- $\mathrm{V}$ shows regression analysis where Korea is a dependent variable and China, USA, Vietnam, Hong Kong, Japan \& Taiwan are independent variables. Coefficient shows higher in the order of USA (0.242), China (0.204) and Japan (0.171). And these countries seem to have had a great impact on Korea's exports. Adjusted R-squared was 0.778, and Korea's variation showed $77.8 \%$ explanatory power. Durbin-Watson stat is 2.954, which means the market moves independently from each other in two countries. China, USA, Hong Kong, Japan and Taiwan were statistically significant at $\mathrm{t}$ statistic and p-value $(\leq 0.01)$ except for Vietnam,

\section{B. Model Analysis}

The analysis period in the following figure is monthly data of 2000.01-2018.09, and the unit is \%.

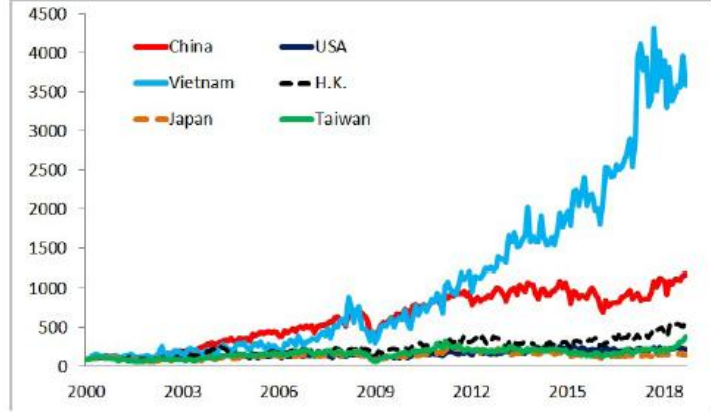

Fig. 7. Monthly Growth Rate - Export Amount
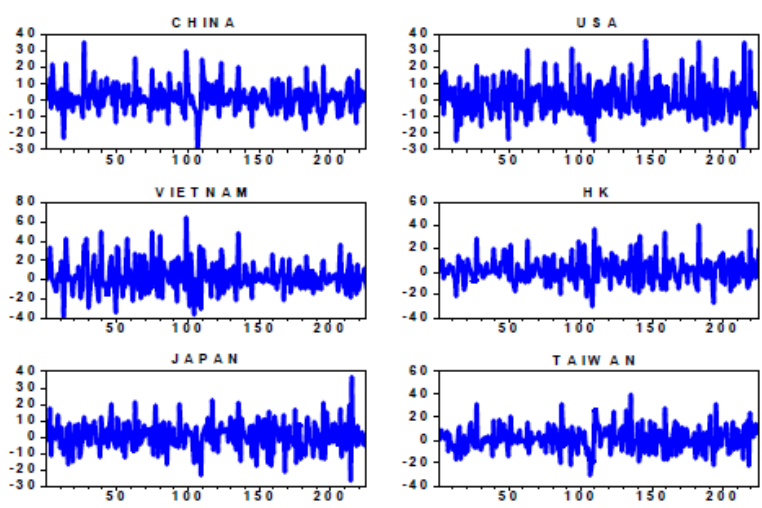

Fig. 8. Monthly Change Rate - Export Amount

Monthly growth rate for each country is shown in Figure 7. Since January 2000, growth rate has been higher in Vietnam $(3,600 \%)$, China $(1,180 \%), \mathrm{HK}(627 \%)$ and Taiwan (380\%). Vietnam is relatively big compared to Japan and the USA and is emerging as a new market.

The change rate of each country is shown in Figure 8. Vietnam, HK and Taiwan are relatively large compared to Japan and China. This change rate means that Vietnam, HK and Taiwan are emerging as new markets.

Figure 9 shows the growth rate distribution of each country. Distribution is widely distributed in the order of Vietnam(-40 +70\%), HK(-40 +50\%), Taiwan(-40 +40\%). Distribution indicates that Vietnam, Hong Kong and Taiwan are emerging as new markets in Korea.

Scatter charts for each country are shown in Figure 10. The $\mathrm{X}$-axis represents Korea's change rate, and the $\mathrm{Y}$-axis represents change rates for each country. The distributions of the US, China and Japan, which have relatively high correlation and low rate of change, are on the whole upward. In the export amount since January 2000, the US, China and Japan seem to have companion with Korea.

Figure 11 shows the Q-Q charts for each country. In the $\mathrm{Q}-\mathrm{Q}$ charts, the baseline (red line) represents the 1: 1 change rate of the $\mathrm{X}$ and $\mathrm{Y}$ axes. Vietnam, HK and Taiwan are relatively wider distribution than the US and Japan. There are a lot of abnormal surges and falls in the top and bottom of the whole. 

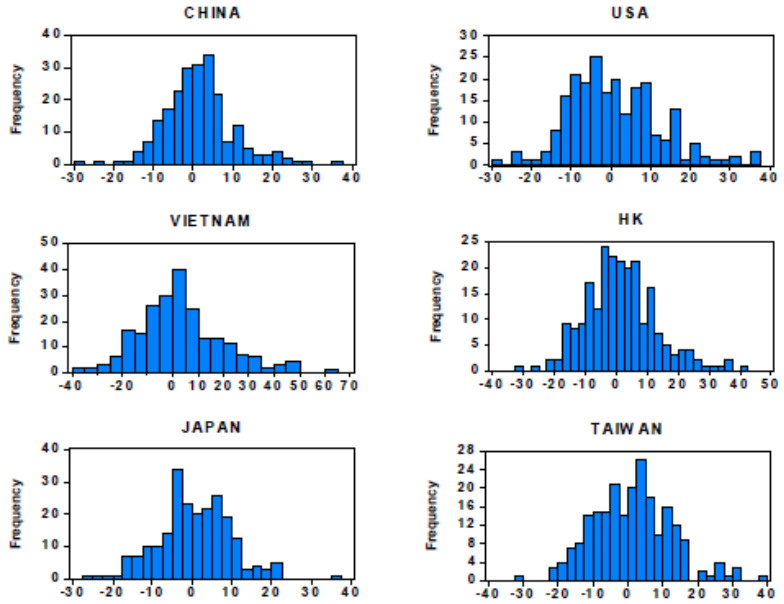

Fig. 9. Monthly Distribution - Export Amount
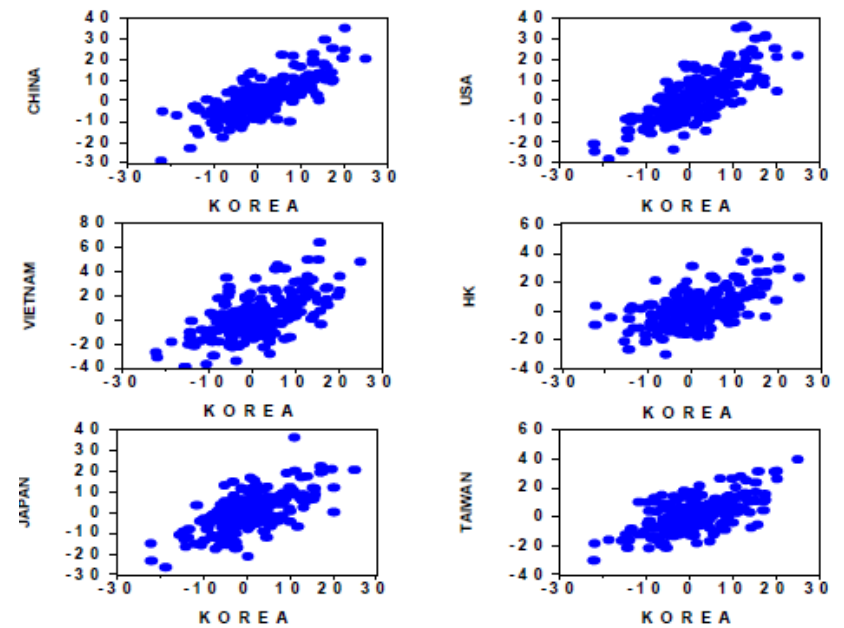

Fig. 10. Scatter Chart - Export Amount
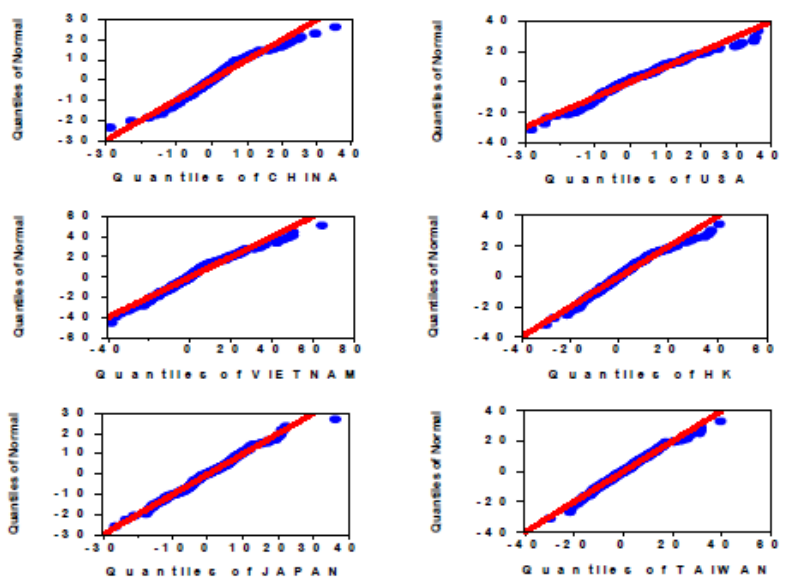

Fig. 11. Quantile-Quintile Plot - Export Amount

The exported box plots for each country are shown in Figure 12. Box-Plot shows a method for graphically depicting groups of numerical data through their quartiles. Vietnam, Hong Kong and Taiwan have relatively large change rate compared to Japan, China and US. In China, Vietnam and Hong Kong, a number of point $(\mathrm{O}, *)$ are shown at the top. This indicates that the abnormal surge occurred frequently. In Japan, the surge was relatively small, and the upward trend seems to have remained constant. Figure-XII shows Missing and Extreme values(Lower limit, Upper limit) by missing value analysis. Missing and extreme values are shown in Figure 12 \& Table-VI.
C H IN A

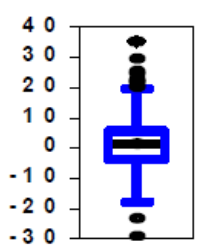

H K

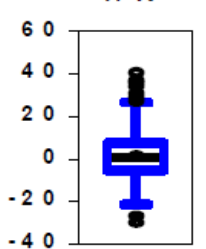

U S A

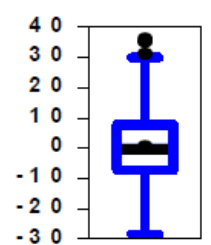

J A P A N

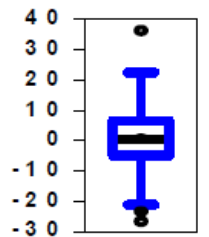

VIE T N A M

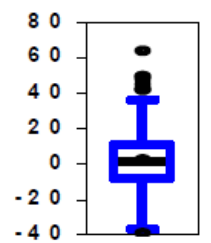

T A IW A N

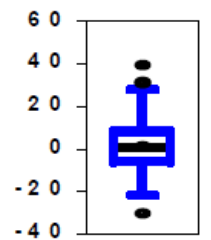

Fig. 12. Box-Plot - Export Amount

Table-VI shows Missing and Extreme values (Lower limit, Upper limit) by missing value analysis. Missing and extreme values are shown in Figure 12. In China, Vietnam, Hong Kong, USA and Taiwan, the upper limit is 9, 8, 8, 5 and 4 at the top, respectively.

Table-VI Missing Value Analysis

\begin{tabular}{c|c|c|c|c|c|c|c}
\hline & & Mea & & \multicolumn{2}{|c|}{ Missing } & \multicolumn{2}{c}{ Extreme Value* } \\
\cline { 5 - 8 } & $\mathbf{N}$ & $\mathbf{n}$ & $\mathbf{S , ~ D ,}$ & $\mathbf{F r e q}$ & $\mathbf{\%}$ & $\begin{array}{c}\text { Lower } \\
\text { limit }\end{array}$ & $\begin{array}{c}\text { Upper } \\
\text { limit }\end{array}$ \\
\hline China & 225 & 1.471 & 8.707 & 0 & .0 & 3 & 9 \\
USA & 225 & .979 & 11.359 & 0 & .0 & 0 & 5 \\
Vietna & 225 & 2.939 & 16.810 & 0 & .0 & 1 & 8 \\
m HK & 225 & 1.460 & 11.549 & 0 & .0 & 2 & 8 \\
Japan & 225 & .630 & 9.257 & 0 & .0 & 2 & 1 \\
Taiwan & 225 & 1.210 & 11.239 & 0 & .0 & 1 & 4 \\
\hline
\end{tabular}

*. Number of cases out of Range (Q1 - 1.5* IQR, Q3 + 1.5* IQR)

\section{CONCLUSION}

This study analyzed trends and directions in the number of exports, exports amount, the number of imports and imports amount of Korea to China, USA, Vietnam, Hong Kong, Japan and Taiwan. The analysis period is from January 2000 to September 2018. In the growth rate analysis, Vietnam showed $780 \%$ the number of exports, 3,000\% exports amount, $2,400 \%$ the number of imports and 6,200\% imports amount. For the past 19 years, Vietnam has shown the highest growth rate compared to other countries.

The correlation between the number of exports, export amount, the number of imports and import amount showed that the value of export amount and import amount was as high as 0.960 . In the monthly regression analysis of exports, China, USA, Hong Kong, Japan and Taiwan were statistically significant at t-statistic and p-value $(\leq 0.01)$ except for Vietnam. Adjusted R-squared was 0.778 , and the variation of the dependent variable Korea showed an explanatory power of $77.8 \%$. The Durbin-Watson stat is

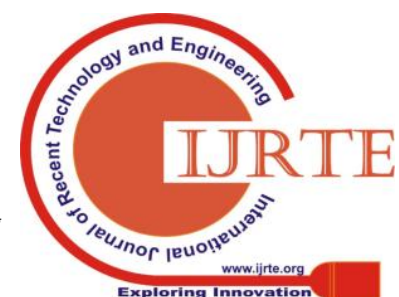


2.954, which means the market moves independently of each other. The model analysis was done through the growth rate, change rate, distribution chart, scatter chart, Quantile-Quantile plot, impulse response, cross correlation and box plot.

The results of this study show that Vietnam, Hong Kong and Taiwan have relatively high growth and change rate compared to USA and Japan which are past export markets. Recently, Southeast Asian markets including Vietnam, Hong Kong and Taiwan have emerged as new export markets. In addition, more attention is needed to Asian markets including India, Singapore, Thailand, Malaysia and the Philippines. It is necessary to diversify the export market and the import market because the export amount and the import amount are increasing in proportion to each other. This paper will help diversify Korea 's major exporting and importing countries in the future.

\section{REFERENCES}

1. Choi M. S. China's Export to World and Korea's Export to China: ARDL Bound Testing Approach, Journal of international trade and insurance, 2017;18(1): 277-296.

2. Choi E. H. The Relationship between Korean Direct Investment and Exports to China: Focused on the Investment of Korean Firms to Shaanxi Province, The Northeast Asian Economic Journal, 2017; 29(3): 59-86.

3. Yoo G. H. A Study on the Logistics Strategy for Expansion Export of Cross Border Trade to China, The international commerce \& law review, 2017; 74:81-103.

4. Kang S. G. An Analysis of Korea's Agricultural Product Competitiveness in China, E-trade review, 2016, 14(2): 151-173.

5. Kim W. J. The Effect of Korea's FDI to China on Korea's Exports to United States, The Northeast Asian Economic Journal, 2017, 29(4): $1-19$.

6. Kim J. Y. Analyzing Export Competitiveness of Korea's Major Automobile Parts to U.S Market due to KORUS FTA, Journal of international trade \& commerce, 2017;13(6): 371-384.

7. Cha K. S \& Kim Y. S. The Effects of an Increase in the Federal Funds Rate on the Exports of Korean Manufacturing Industry, International Economic Journal, 2018, 22(4): 87-120.

8. Shim J. H. An Analysis of Comparative Advantage and Intra-Industry Trade in Korean Export Industry in Respect to Korea-U.S. FTA, Journal of International Commerce and Information, 2017; 19(4): 175-197.

9. Kim C. B. et al. The Effect of Foreign Direct Investment on Export Inducement and Trade Complementary in Vietnam Market, The e-business studies, 2017;18(6): 215-228.

10. Choi D. O. et al. Pattern Analysis of Korea's Exports to Vietnam by Sea and Air, The Korean international commerce review, 2015;30(4): 247-262.

11. Lee, J. H. (2012), Analysis of Determinants of Export Competitiveness in Vietnam Market of Korean Companies, Korea trade review, 37(4), 139-160.

12. Lee S. Y. \& Lee J. G. Sustainable Supply Chain Management and Performance of Global Supply Chain: An Empirical Study on Vietnamese Export-oriented Suppliers, Korean journal of business administration, 2015; 28(2): 453-468.

13. Lee Y. H, Korean pig seems competitive: Hong Kong and Macao Consumers 70\% "Purchasing", JoongAng Daily Economic General, 2018.03.20. https://news.joins.com/article /22457021

14. Jung B. N. Nonghyup Expands Pork Export to Hong Kong Market, Yunhap News, 2017.05.12. http://www.yonhapnews.co.kr/bulletin/2017/05/12/

15. Ministry of Agriculture, Food and Rural Affairs. (2018), Domestic chicken, eggs, Hong Kong export resumed!!, MAFRA Press Releases, 2018.7.30. http://www.mafra.go.kr/mafra/293/subview.do?enc=

16. Oh T. H. A Study on the Changes in the Japanese Import Market and Korea's Exports to Japan: Focusing on the Cases Concerning Apparel Industry Creature, Korea-Japan Economic Journal, 2017;75: 189-210.

17. Kwon Y. U, Nam G. D. A Study on the Changes of the Competition Structure of the Japanese Electronics \& Electrical Products Market and the Korean Enterprises' Strategies of Export to Japan, Journal of international trade \& commerce, 2013;9(1): 71-99.

18. Kwon Y. U, Nam G. D. An Empirical Study on the Changes of the Competition Structure of the Japanese Market and the Korean Enterprises' Strategies of Export to Japan, Journal of customs and trade, 2013;14(3): 207-225. http://uci.or.kr/G704-001591.2013.14.3.010

19. Jung H. S \& Im D. H. A Study on the Changes of Export Competitive Advantage Pattern of Global ICT Industry: Focusing on Korea, China and Japan, Korea-Japan Economic Journal, 2018; 79: 67-91.

20. Lim C. R. et al. Effect of the GAP Certification on Taiwanese Consumers' Preferences, Korean journal of agricultural management and policy, 2011; 38(2): 239-254.

21. Choi S. I. Best to produce the best pear: C. K. Lee, CEO, exporting pear to Taiwan, Palm \& Market Magazine, 2017; 19: 32-33. http://www.farmnmarket.com/news/article.html?no=2787

22. Jung H. C. Kimchi export, As of September this year, it increased by $8.5 \%$, and diversified markets such as USA and Taiwan increased exports: Kimchi Export Status and Tasks, Food Journal, 2016;232: 34-36.

23. KOMMA. Japan and the United States continued to decline and Taiwan increased exports, Machine Tool, 2016;288: 26-27.

24. Korea International Trade Association. Expected to expand IT products export to ITA II : Exports to China, ASEAN, and Taiwan are expected to expand to include optical and medical devices, KITA Press Releases, 2016.05.03.

\section{AUTHORS PROFILE}

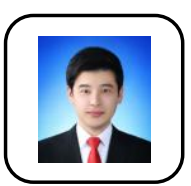

S00-Ho, Choi

Feb. 2011: Korea Aerospace University School of Air Transport, Transportation and Logistics

Feb. 2016: Sogang University Graduate school, Business Administration (MBA)

Apr. 2016 -: Sogang University Graduate school, Business Administration (Ph.D. in Business Administration)

Interests: SCM, GVC, Logistics, Service Management

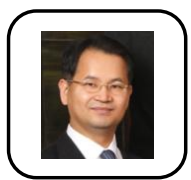

\section{Jeong-II, Choi}

Feb. 1983: Sogang University Department of Mathematics

Feb. 1997: Sogang University Business School (MBA)

Feb. 2005: Myeongji University Graduate School (Ph.d.)

Apr. 2006 -: Professor, School of Business, Sungkyul University

Interests: Financial Management, Investment 